\title{
Nutrient Accumulation, Partitioning, and Remobilization by two Sesame (Sesamum indicum L.) Cultivars
}

\author{
H. Laurentin ${ }^{*}$ and V. Rodriguez ${ }^{2}$ \\ Date Received: $15^{\text {th }}$ October 2019 / Date Accepted: $10^{\text {th }}$ February 2020
}

\begin{abstract}
Purpose: Sesame (Sesamum indicum L.) is an important crop in tropical areas. Differences between potential and actual yield is caused by several causes. One is the deficiency of basic information for establishing comprehensive fertilization plans, due to inadequate information of mineral nutrition. The aims of the study were to determine macronutrients and micronutrients accumulation, partitioning, and remobilization by two sesame cultivars.
\end{abstract}

Research Method : A field experiment was established to obtain biomass enough in four growth stages: vegetative, mid-flowering, late flowering, and harvest. Biomass and content of nitrogen, phosphorous, potassium, calcium, magnesium, sodium, cupper, iron, zinc, and manganese were determined from vegetative tissues for the first two growth stages, and in seed and rest of the plant for the last two growth stages.

Findings : For both cultivars, the decreasing order of the macronutrient according the amount accumulated was nitrogen, potassium, calcium, phosphorous, magnesium, and sodium. Decreasing order of micronutrients was iron, zinc, copper, and manganese. More than $30 \%$ of the nutrient extraction accumulated in seed was identified for nitrogen, phosphorous, and zinc. Results suggest calcium remobilization for both cultivar, and only for one of them for nitrogen, phosphorous, and magnesium.

Originality / Value : Results of this study establish the basis of the understanding of sesame nutrition. Future fertilization plans must use this information for an efficient use of fertilizers.

Keywords: fertilization, macronutrient, micronutrient, mineral nutrition, nutrient content

\section{INTRODUCTION}

Sesame (Sesamum indicum L.) belongs to family Pedaliaceae, which is grown mainly in tropical areas. This important oilseed is cultivated on more than 10 million of hectares in Africa, America and Asia for producing more than 6 million tons of grains per year (Food and Agriculture Organization [FAO], 2019). Sesame seed is mainly used for oil extraction because of its high oil content in the grain (44\%-58\%), and due to the high content of unsaturated fatty acids and antioxidants (Fukuda et al., 1986). Sesame grains are also used for direct consumption due to protein content (18\%-25\%), and special flavor. At the present, several countries are exporting sesame products. Sesame production in the field is very marginal as compared to potential yield, indicating sesame has a big potential to increase total production. However, there are restrictions about knowledge and information, mainly in aspects related to management of the crop such as fertilization. Any effort to increase the production of sesame, requires expanding knowledge about the mineral nutrition of this species. This knowledge could optimize fertilization in sesame production areas, resulting in more efficient production processes.

Crop fertilization plans need to know plant

I* Department of Biologic Sciences. Faculty of Agronomy,
Universidad Centroccidental Lisandro Alvarado.
Barquisimeto,Venezuela.
hlaurentin@ucla.edu.ve
2 Department of Plant Sciences, Faculty of Agronomy,
$\begin{aligned} & \text { Universidad Centroccidental Lisandro Alvarado. } \\ & \text { Barquisimeto, Venezuela. }\end{aligned}$

(D) ORCID http://orcid.org/0000-0001-6222-3566 
nutrient requirements (Sadeghian-Khalajabadi et al., 2006; Arriel et al., 2007; Dos Santos et al., 2018), and they depend on crop species, variety, weather, and soil (Havlinet al., 1999). It is important to know potential uptake of each nutrient at different plant growth stages for one variety, in order to plan fertilizing according to weather and soil of location as crops area normally cultivated. Plants require thirteen essential mineral nutrients to accomplish its metabolism without restrictions. According to the amount required, these nutrients are classified into macro and micronutrients. Nitrogen $(\mathrm{N})$, phosphorous $(\mathrm{P})$, and potassium $(\mathrm{K})$ are considered as primary macronutrients because of the large amount the plants need (Breglianiet al., 2006). Calcium (Ca), magnesium $(\mathrm{Mg})$, and sulphur (S) are classified as secondary macronutrients. Sodium $(\mathrm{Na})$ has also been considered as an essential nutrient (Kronzuckeret al.,2013). Micronutrients are boron $(\mathrm{B})$, chrorine $(\mathrm{Cl})$, copper $(\mathrm{Cu})$, iron $(\mathrm{Fe})$, manganese $(\mathrm{Mn})$, molybdenum (Mo), and zinc (Zn).

Despite, there are several studies for sesame about influence of nitrogen fertilization (Bregliani et al., 2006; Badshah et al., 2017; Dos Santos et al., 2018), sulfur fertilization (Jat et al., 2017), and N-P-K fertilization (Shehu, 2014) on production of the crop, studies about sesame mineral nutrition are scarce. Almost all the works related to nutrient uptake in sesame did not consider uptake related to growth stages of the plant. Except a paper by Couch et al. (2017), all the works reported nutrient accumulation at the end of the harvest, therefore, no information is available on amount of nutrient uptaken in different growth stages, and thus it is not possible to design efficient fertilization plans. Patterns of nutrient uptake, partitioning, and remobilization are needed to understand the physiology of nutrient accumulation (Benderet $a l ., 2015)$, and for getting this information, it is necessary to evaluate at different growth stages. Although this approach has been used recently in major crops such as soybean (Gasparet al., 2017), maize (Yuhuiet al., 2019), wheat (Zhouet al.,2018) and rice (Sanchez-Reinosoet al.,2019), similar studies for sesame have been performed only for nitrogen by Couch et al.
(2017).

The objectives of this research were to determine accumulation, partitioning, and remobilization of nitrogen, phosphorous, potassium, calcium, magnesium, copper, iron, manganese, zinc, and sodium in two sesame cultivars.

\section{MATERIALS AND METHODS}

\section{Field site and plant material}

A field trial was established in location Chorrerones (106 meters above sea level, coordinates $9^{\circ} 11^{\prime} 26^{\prime \prime} \mathrm{N}$ and 68 59'42' W), Portuguesa state, Venezuela, at the same season in which sesame is commercially grown. The area where trial was established is characterized by having an average annual rainfall of 1466 $\mathrm{mm}$, from which only $6 \%$ falls between November and April (months of sesame cultivation); the average annual evaporation is $1763 \mathrm{~mm}, 30 \%$ occurring between November and April. Two sesame cultivars were planted: Fonucla (Montilla and Cedeño, 1991), and UCLA90 (Laurentinet al., 2004). Eight rows (25 m length, separated $0.60 \mathrm{~m}$ ) were planted for each cultivar, at 12 seeds per lineal meter, resulting in an approximate population density of 200,000 plants per hectare. Sesame plants took advantage of the residual moisture in the soil, without irrigation, without fertilization, such as Venezuelan sesame production is performed.

\section{Biomass sampling}

Sampling area consisted in 4 rows of $20 \mathrm{~m}$ length for each cultivar (the central rectangle of the total area planted with each cultivar), assuring all the plants sampled for each cultivar had around only plants of the same cultivar. Soil was sampled in 10 points for each rectangle, from 0 to $5 \mathrm{~cm}$, and from 5 to $10 \mathrm{~cm}$, in deep. Four growth stages were sampled for both cultivars: vegetative (samples were taken when first buds appeared in less than 10\% of plants), mid-flowering (samples were taken when 90\% of the plants had branches in which flowering stopped), late flowering (samples were taken when $90 \%$ of plants did not have open flowers 
anymore), and harvest (samples were taken when capsules were mature, taking as indicator when capsules at bottom were totally dried and open). These four growth stages do not have same duration for FONUCLA and UCLA90; therefore, samples for FONUCLA were taken at the days $34,60,72$, and 82 after planting, and for UCLA90 they were obtained at the days 29, 52, 66, and 73 after planting. Each growth stages was represented by the samples taken at 1 linear meter (approximately 12 plants) chosen randomly in the sampling area, using 10 replications. Samples were represented by whole plants.

\section{Laboratory analyses}

All laboratory analyses were performed in Soil and Mineral Nutrition Research Unit, which belongs to Agronomy Faculty of Universidad Centroccidental Lisandro Alvarado, Venezuela. Soil samples were dried and sieved to $2 \mathrm{~mm}$. Suspension soil:water 1:2 was used to determine $\mathrm{pH}$ and electrical conductivity $\left(\mathrm{dS} \mathrm{m}^{-1}\right)$. Texture $\left(\mathrm{g} \mathrm{kg}^{-1}\right)$ was determined by Bouyoucos method. Organic matter $\left(\mathrm{g} \mathrm{kg}^{-1}\right)$ was determined by Walkley and Black method. $\mathrm{Ca}, \mathrm{Mg}$, and $\mathrm{K}$ $\left(\mathrm{cmolc} \mathrm{dm}^{-3}\right.$ ) were extracted using a solution of ammonium acetate $1 \mathrm{~N} \mathrm{pH} 7.0$ (Rodríguezet al., 2009); K was quantified by photometry, and $\mathrm{Ca}$ and $\mathrm{Mg}$ by atomic absorption. Phosphorous ( $\mathrm{mg}$ $\mathrm{kg}^{-1}$ ) was extracted with sodium bicarbonate $0.5 \mathrm{M} \mathrm{pH} 8.5$ and quantified by colorimetric procedure.

Plant samples were washed with distillated water and chlorhydric acid solution $(0.5 \%)$ for 5 minutes. Samples were dried in paper bags placed in stove at $70{ }^{\circ} \mathrm{C}$ for $48-72$ hours until reach constant weight. Samples of the growth stages Vegetative and Flowering were represented by the whole plant; samples of the growth stages Late Flowering and Harvest consisted in two sub-samples: vegetative tissue (root, stem, leaves, flower, and empty capsules), and seeds. Weight of dry matter of each sample was determined. Samples were ground to pass a $2 \mathrm{~mm}$ mesh screen in a Wiley mill, $0.5 \mathrm{~g}$ of dried tissue was digested by incineration at $500{ }^{\circ} \mathrm{C}$ for 5 hours, and dissolved in nitric acid $32.5 \%$. Elements $\mathrm{K}, \mathrm{Ca}, \mathrm{Mg}, \mathrm{Cu}, \mathrm{Fe}, \mathrm{Mn}, \mathrm{Zn}$, and $\mathrm{Na}$ were quantified by atomic absorption spectrometry; $\mathrm{N}$ by Kjeldahl method, and $\mathrm{P}$ by metavanadate method. The quantity of nutrients accumulated by sesame on each growth stage within each replication was determined by multiplying the dry weight of tissues of each the growth stage (for each replication) by percent of each nutrient determined in the $0.5 \mathrm{~g}$ of dry matter.

\section{Determination of nutrient accumulation and total uptake}

Nutrient accumulation was determined for each cultivar at each growth stage, and accumulation for one individual plant was estimated based on the sample of 12 plants in one linear meter. In order to calculate nutrient accumulation expressed in $\mathrm{kg} \mathrm{ha} \mathrm{ha}^{-1}$, accumulation of one individual plant was multiplied by 200.000 plant per hectare. Total uptake of nutrients for each cultivar was estimated from nutrient accumulation at the last growth stage (harvest).

\section{Determination of nutrient partitioning}

Nutrient partitioning was determined in the growth stages where organs were separated: late flowering and harvest. Nutrients were determined in root, stem, leaves, flowers, empty capsules, and seeds, where main factors were Cultivar, Part of the Plant, and interaction Cultivar x Part of the Plant.

\section{Determination of nutrient remobilization}

Nutrient remobilization was identified as Couch et al., (2017). Briefly, remobilization was identified when nutrient content of vegetative tissue at harvest was lower than nutrient content of vegetative tissue at late flowering; and it was determined by subtracting nutrient content of vegetative tissue at harvest from nutrient content of vegetative tissues at late flowering.

\section{Statistical analysis}

Analysis of variance performed under factorial design, was used to determine differences in nutrient content in soil. Sampling Areas, and Depth, with 10 replications, were the main factors when soil properties, and nutrients found in the soil were analyzed individually. 
For tissues, the main factors were Cultivars, and Growth Stages when biomass was analyzed; 10 replications were used for this analysis.

Analysis of variance for individual nutrient accumulation was performed in a similar way of the analysis for biomass in tissues. Analysis of variance was also performed for nutrient partitioning in plant (root, stem, leaves, flowers, and empty capsules), and seeds, where main factors were Cultivar, Part of the Plant, and interaction Cultivar x Part of the Plant.

In addition to ANOVA for determining differences among nutrients in soil and tissues, a Harvest Nutrient Index was calculated to know the efficiency in the use of the nutrients for each cultivar. Harvest Nutrient Index (HNI) was calculated for each nutrient utilizing the equation:

$$
\mathrm{HNI}=(\mathrm{NS} / \mathrm{NP}) \times 100
$$

where NS is nutrient content in seed, and NP is nutrient content in the whole plant (including seed).

\section{RESULTS AND DISCUSSION}

Analyses of variance resulted in no differences neither between the two levels of depth nor between the two sampling areas, therefore, soil properties and nutrient content were averaged on depth and sampling areas (Table 01). According to criteria of Soil and Mineral Nutrition Research Unit of Agronomy Faculty at Universidad Centroccidental Lisandro Alvarado, soil in the sampling areas has a silty clay loam texture, high $\mathrm{pH}$, and low electrical conductivity and organic matter. Content of calcium and phosphorous was high, whereas magnesium in the soil was low. Potassium presented an intermediate content.

Biomass accumulation resulted significant for the interaction Cultivar x Growth Stage, indicating there are differences between cultivars when biomass accumulation patterns are compared. Couch et al. (2017) also reported this kind of Genotype x Environment interaction when evaluated 4 cultivars through
5 growth stages. Growth of cultivars UCLA90 and Fonucla is slow at the beginning of the crop cycle, as reported in sesame (Ribeiro et al., 2018). Differences in biomass accumulation between both cultivars are evident from the moment of stopping flowering in the branches (mid-flowering) until there are no open flowers in the whole plant (late flowering or grain filling). Fonucla is a taller and more rustic cultivar than UCLA-90 (Laurentin et al., 2004) and therefore, it had the highest biomass accumulation from flowering (Figure 01). From the total biomass, seeds represented at the harvest $21.1 \%$ for UCLA-90 and $15.5 \%$ for Fonucla, which are close to the extremes of the range for harvest index in sesame (Badshah et al., 2017; Jat et al., 2017). According to these harvest indices, UCLA-90 appears as more efficient cultivar than Fonucla.

Fonucla accumulated higher total amount of each nutrient than UCLA-90 because of Fonucla is represented by more robust plants than UCLA90. Accumulation of nitrogen, phosphorous, magnesium, zinc, iron, and manganesum had a significant effect $(\mathrm{P}<0.05)$ for the interaction Cultivar $\mathrm{x}$ Growth Stage, for the other nutrients, there was not interaction effect $(\mathrm{P}>0.05)$. Figures 02 and 03 show nutrient accumulation through the Growth Stages for each cultivar. Accumulation of macronutrients nitrogen, phosphorous, and magnesium had an interaction Cultivar $x$ Growth Stage because pattern of nutrient accumulation was the same than biomass accumulation pattern for each cultivar. For these nutrients, interaction was reflected as changes in the magnitude of the extraction through growth stages according to the cultivar. For extraction of micronutrients zinc, iron, and manganese, interaction was represented as changes in order of nutrient amount through growth stages according to the cultivar: iron, and zinc were accumulated by UCLA-90 in higher amount than Fonucla for the first two growth stages, but for Late Flowering, and Harvest, Fonucla accumulated more than UCLA90. Interaction for manganese accumulation was different, UCLA-90 accumulated more than Fonucla for the first three growth stages, and Fonucla more than UCLA-90 for the last growth stage. Nutrient accumulation with no 
interaction (potassium, calcium, sodium, and higher nutrient accumulation than UCLA-90 cupper) followed the trend of Fonucla having for all growth stages.

Table 01: Average and standard deviations values of soil properties and nutrient content of sampling area

\begin{tabular}{|c|c|c|c|c|c|c|c|}
\hline \multicolumn{8}{|c|}{ Soil properties } \\
\hline $\begin{array}{l}\mathrm{pH} \\
1: 2\end{array}$ & \multicolumn{2}{|c|}{$\begin{array}{c}\text { Electrical } \\
\text { conductivity } \\
\left(\mathrm{dS} \mathrm{m}^{-1}\right)\end{array}$} & $\begin{array}{l}\text { Organic matter } \\
\qquad\left(\mathrm{g} \mathrm{kg}^{-1}\right)\end{array}$ & $\begin{array}{l}\text { Sand content } \\
\quad\left(\mathrm{g} \mathrm{kg}^{-1}\right)\end{array}$ & \multicolumn{2}{|c|}{$\begin{array}{l}\text { Loam Content } \\
\qquad\left(\mathrm{g} \mathrm{kg}^{-1}\right)\end{array}$} & $\begin{array}{l}\text { Clay content } \\
\quad\left(\mathrm{g} \mathrm{kg}^{-1}\right)\end{array}$ \\
\hline 7.17 & $0.44=$ & \pm 0.02 & $29.20 \pm 1.83$ & $206.70 \pm 10.11$ & 506.90 & \pm 4.26 & $286.50 \pm 1.41$ \\
\hline \multicolumn{8}{|c|}{ Nutrients } \\
\hline $\begin{array}{c}\mathrm{P} \\
\left(\mathrm{mg} \mathrm{kg}^{-1}\right)\end{array}$ & $\begin{array}{c}\mathrm{K} \\
(\mathrm{cmolc} \\
\left.\mathrm{dm}^{-3}\right) \\
\end{array}$ & $\begin{array}{c}\mathrm{Ca} \\
(\mathrm{cmolc} \\
\left.\mathrm{dm}^{-3}\right) \\
\end{array}$ & $\begin{array}{c}\mathrm{Mg} \\
(\mathrm{cmolc} \\
\mathrm{dm}^{-3} \text { ) } \\
\end{array}$ & $\begin{array}{c}\mathrm{Cu} \\
\left(\mathrm{mg} \mathrm{kg}^{-1}\right)\end{array}$ & $\begin{array}{c}\mathrm{Fe} \\
\left(\mathrm{mg} \mathrm{kg}^{-1}\right)\end{array}$ & $\begin{array}{c}\mathrm{Mn} \\
\left(\mathrm{mg} \mathrm{kg}^{-1}\right)\end{array}$ & $\begin{array}{c}\mathrm{Zn} \\
\left(\mathrm{mg} \mathrm{kg}^{-1}\right)\end{array}$ \\
\hline $91.77 \pm 5.28$ & $0.27 \pm 0.01$ & $18.30 \pm 0.98$ & $0.46 \pm 0.02$ & $5.04 \pm 0.02$ & $19.42 \pm 2.31$ & $3.60 \pm 0.22$ & $3.81 \pm 0.47$ \\
\hline
\end{tabular}

Figure 01: Biomass accumulation of two sesame cultivars during four growth stages. Average values with the same letter do not differ $(\mathbf{P}<\mathbf{0 . 0 5})$
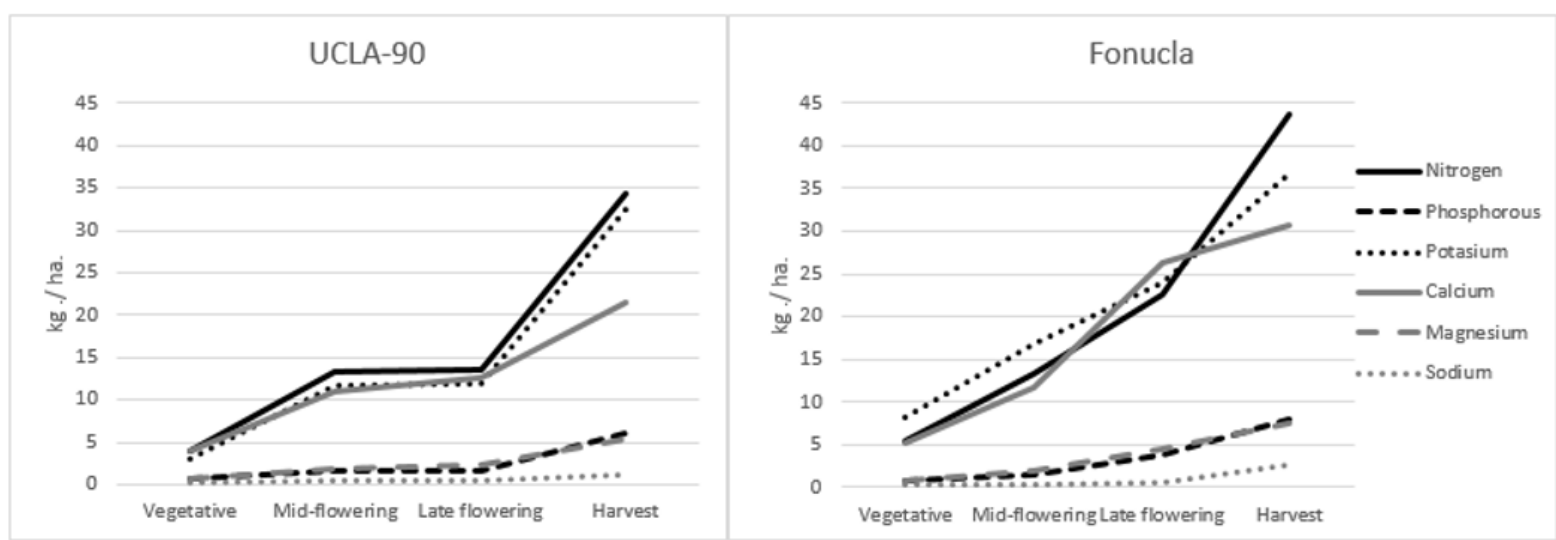

Figure 02: Accumulation of macronutrients and sodium in two sesame cultivars through four growth stages 

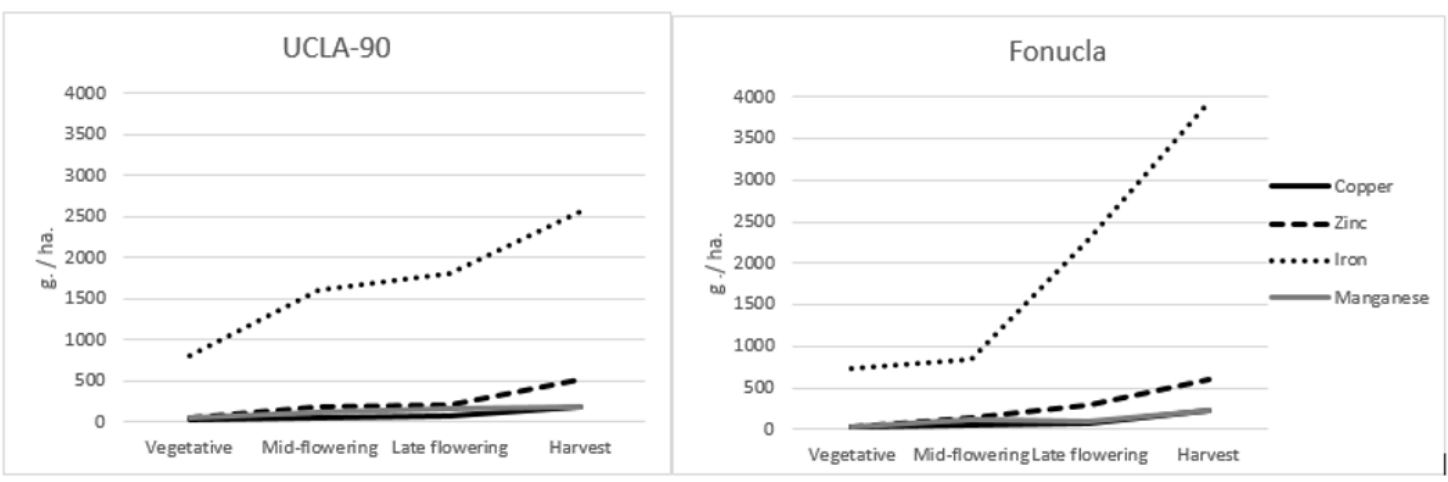

Figure 03: Accumulation of micronutrients in two sesame cultivars through four growth stages

Dynamic of nutrient accumulation was different when both cultivars were compared. Because of absolut amount of nutrients is different when UCLA-90 is compared to Fonucla, percentage of each nutrient at each growth stage was determined for comparison between both cultivars (Table 02). For both, cultivar calcium is one of the two most extracted macronutrient at the three first growth stages; also common for both to extract half or more of the macronutrients nitrogen, phosphorous, and potassium, and the micronutrients zinc and cupper at the last two growth stages. Magnesium is extracted by the two cultivars in at least $60 \%$ at the three first growth stages. For both cultivars, macronutrients nitrogen, phosphorous, and potassium were extracted in at least $60 \%$ of total extraction at the last two growth stages.
Manganese extraction for both cultivars reach at least $65 \%$ of total extraction at the first two growth stages.

Nutrient partitioning in seed, and rest of the plant, resulted in significant interaction $(\mathrm{P}<0.05)$ Cultivar $\mathrm{x}$ Part of the Plant for nitrogen, phosphorous, and magnesium (Figure 04). This interaction was explained because of the difference in accumulation pattern between nutrient content at Late Flowering and nutrient content at Harvest between UCLA-90 and Fonucla. UCLA-90 accumulated more nitrogen, phosphorous, and magnesium at Harvest in the vegetative tissue at Late Flowering than at Harvest; while on the contrary, Fonucla accumulated more of these nutrients at Harvest than at Late Flowering.

Table 02: Percentage of the two most extracted macronutrients and micronutrients through four growth stages in two sesame cultivars

\begin{tabular}{|c|c|c|c|c|}
\hline \multirow[b]{2}{*}{ Growth stage } & \multicolumn{2}{|c|}{ UCLA-90 } & \multicolumn{2}{|c|}{ Fonucla } \\
\hline & Nutrient & $\begin{array}{l}\text { Percent of the total } \\
\text { extracted }\end{array}$ & Nutrient & $\begin{array}{l}\text { Percent of the total } \\
\text { extracted }\end{array}$ \\
\hline \multirow{4}{*}{ Vegetative } & Calcium & 18 & Potassium & 22 \\
\hline & Magnesium & 13 & Calcium & 17 \\
\hline & Manganesium & 33 & Iron & 18 \\
\hline & Iron & 31 & Copper & 16 \\
\hline \multirow{4}{*}{ Mid-flowering } & Calcium & 33 & Potassium & 23 \\
\hline & Nitrogen & 28 & Calcium & 22 \\
\hline & Manganesium & 39 & Manganesium & 42 \\
\hline & Iron & 31 & Zinc & 18 \\
\hline \multirow{4}{*}{ Late Flowering } & Magnesium & 57 & Calcium & 47 \\
\hline & Calcium & 42 & Magnesium & 34 \\
\hline & Copper & 20 & Iron & 40 \\
\hline & Iron & 10 & Zinc & 24 \\
\hline \multirow{4}{*}{ Harvest } & Potassium & 64 & Phosphorous & 52 \\
\hline & Phosphorous & 44 & Nitrogen & 48 \\
\hline & Zinc & 55 & Copper & 64 \\
\hline & Copper & 48 & Zinc & 52 \\
\hline
\end{tabular}



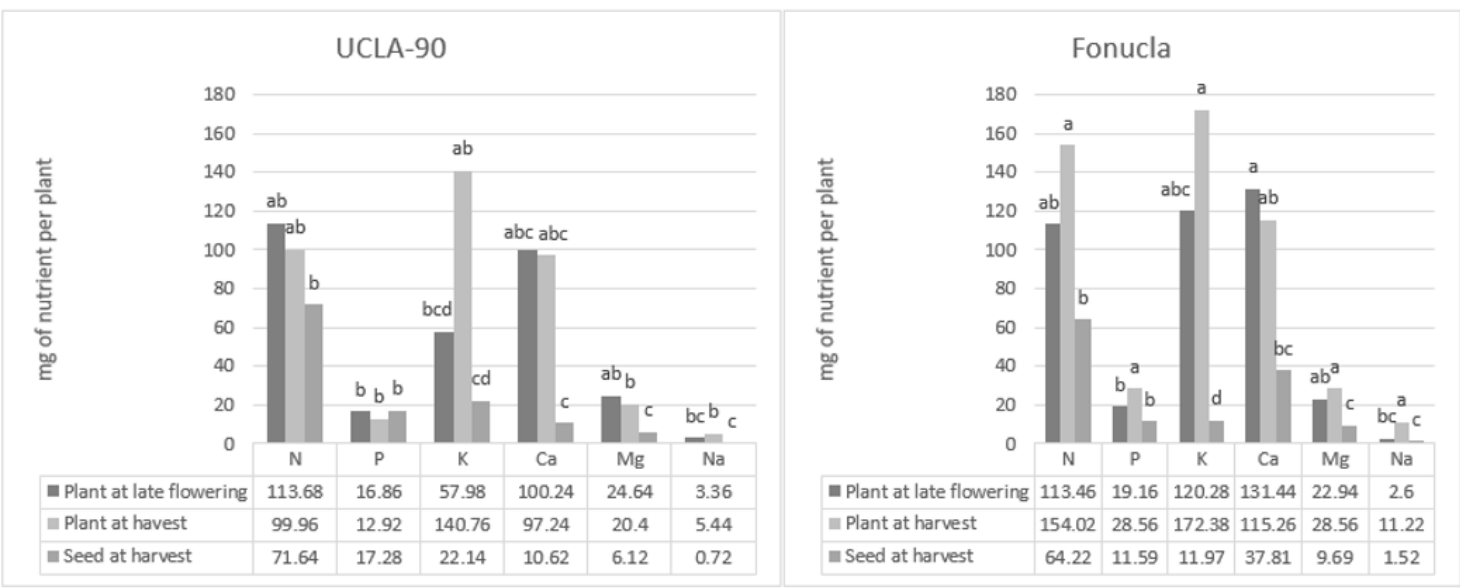

Figure 04: Content of macronutrients in sesame cultivars UCLA-90, and Fonucla, for plant in late flowering, plant in harvest, and seed in harvest. For each nutrient, bars with the same letter do not differ $(\mathbf{P}<\mathbf{0 . 0 5})$

This fact indicates nutrient remobilitation in UCLA-90 from vegetative tissue to seeds: $12 \%$ for nitrogen, $23 \%$ for phosphorous, and $17 \%$ for magnesium. Calcium did not present interaction, but for both cultivars seems to be remobilisated from vegetative tissue to seeds: $3 \%$ in UCLA90, and $12 \%$ in Fonucla. There was no evidence of micronutrient remobilization (Figure 05). Nutrient concentration at the seed was similar for both cultivars (Table 03).

Harvest nutrient indexes are displayed in Table 04. UCLA-90 was more efficient than Fonucla in retaining at the seeds the nutrients uptaken such as nitrogen, phosphorous, potassium, cupper, zinc, and manganese. Harvest nutrient indexes (HNI) determined in current work are not similar to HNI determined for other crops such as soybean where nitrogen, phosphorous, and potassium havest indexes resulted in 0.75 ; 0.73 , and 0.45 respectively (Tamagno et al., 2017).

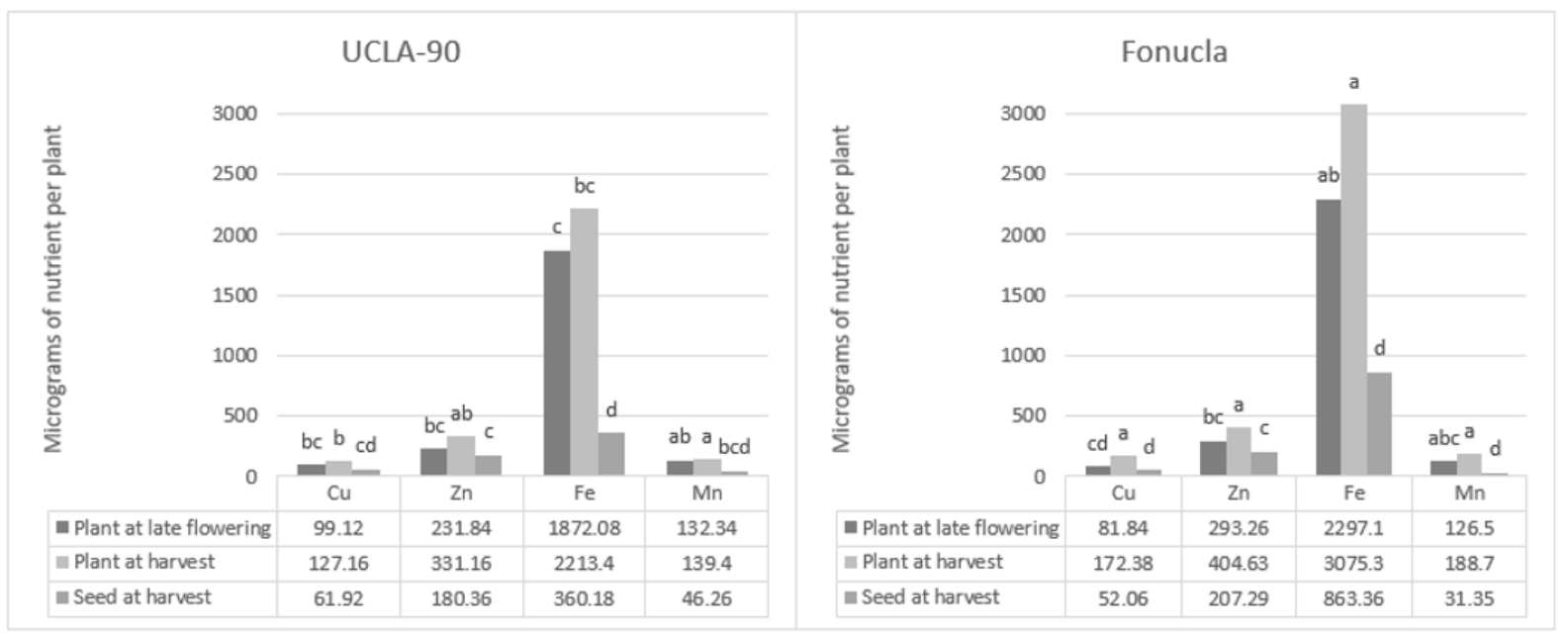

Figure 05. Content of micronutrients in sesame cultivars UCLA-90, and Fonucla, for plant in late flowering, plant in harvest, and seed in harvest. For each nutrient, bars with the same letter do not differ $(\mathbf{P}<0.05)$

Table 03: $\quad$ Nutrient concentration at the seed for two sesame cultivars

\begin{tabular}{|c|c|c|c|c|c|c|c|c|c|c|}
\hline & \multicolumn{6}{|c|}{ Macronutrients (grams per kilogram of seed) } & \multicolumn{4}{|c|}{$\begin{array}{c}\text { Micronutrients (milligrams per kilogram of } \\
\text { seed) }\end{array}$} \\
\hline & $\mathrm{N}$ & $\mathrm{P}$ & K & $\mathrm{Ca}$ & $\mathrm{Mg}$ & $\mathrm{Na}$ & $\mathrm{Cu}$ & $\mathrm{Zn}$ & $\mathrm{Fe}$ & $\mathrm{Mn}$ \\
\hline UCLA-90 & $39.8 \pm 2.1$ & $9.6 \pm 0.8$ & $12.3 \pm 0.9$ & $5.9 \pm 0.1$ & $3.4 \pm 0.1$ & $0.4 \pm 0.0$ & $34.4 \pm 1.58$ & $100.2 \pm 8.9$ & $200.1 \pm 11.4$ & $25.7 \pm 1.1$ \\
\hline Fonucla & $33.8 \pm 2.4$ & $6.1 \pm 0.5$ & $6.3 \pm .0 .4$ & $19.9 \pm 2.0$ & $5.1 \pm 0.2$ & $0.8 \pm 0.0$ & $27.4 \pm 1.6$ & $109.1 \pm 5.1$ & $454.4 \pm 20.2$ & $16.5 \pm 0.9$ \\
\hline
\end{tabular}


Table 04: Harvest nutrient indices for two sesame cultivars

\begin{tabular}{lcccccccccc}
\hline & $\mathrm{N}$ & $\mathrm{P}$ & $\mathrm{K}$ & $\mathrm{Ca}$ & $\mathrm{Mg}$ & $\mathrm{Na}$ & $\mathrm{Cu}$ & $\mathrm{Zn}$ & $\mathrm{Fe}$ & $\mathrm{Mn}$ \\
\hline UCLA-90 & 41.8 & 56.5 & 13.6 & 9.9 & 23.4 & 10.8 & 31.0 & 36.0 & 14.0 & 42.9 \\
Fonucla & 29.2 & 29.1 & 6.8 & 24.5 & 25.2 & 11.2 & 20.0 & 33.3 & 21.5 & 12.0 \\
\hline
\end{tabular}

Total macronutrient extraction expressed in $\mathrm{kg}$ $\mathrm{ha}^{-1}$, what is the same that nutrient accumulation at harvest, was similar to the reported by Baskaret al.(2017) for sesame. These authors indicate that sesame, in average over several treatments and two years, uptook 36, 8, 24, 22, and $5 \mathrm{~kg} \mathrm{ha}^{-1}$ of $\mathrm{N}, \mathrm{P}, \mathrm{K}, \mathrm{Ca}$, and $\mathrm{Mg}$ respectively, values very similar to the 34,6 , 33,22 , and 5 reported here for UCLA-90, and also similar to the $44,8,37,31$, and 8 reported here for Fonucla. Similar values have been found by Shehu (2014) (30 kg ha-1 of nitrogen, $2 \mathrm{~kg} \mathrm{ha}^{-1}$ of phosphorous, and $28 \mathrm{~kg} \mathrm{ha}^{-1}$ of potassium), and by Ramakrishna et al. (2017) ( $5 \mathrm{~kg} \mathrm{ha}^{-1}$ of phosphorous, and $35 \mathrm{~kg} \mathrm{ha}^{-1}$ of potassium). Total macronutrient extraction for both cultivars agree on resuls of Baskar et al. (2017) when indicate macronutrient extraction order: nitrogen is accumulated more than the other macronutrients, followed by potassium, calcium, phosphorous, and magnesium. Patel and Raj (2017) agree to current work indicating that sesame uptakes about $40 \mathrm{~kg} \mathrm{ha}^{-1}$ of nitrogen, however, they reported a phosphorous uptake higher than potassium (about 25 and 21 respectively). Couch et al. (2017) reported nitrogen accumulation at harvest by four sesame cultivars in a range of 70-99 $\mathrm{kg} \mathrm{ha}^{-1}$, however, they tested cultivars with a life cycle longer than 112 days, therefore, these cultivars accumulated more biomass and also nutrients.

Sesame fertilization programmes should consider dynamics of nutrients uptake. Because of demand of nitrogen, phosphorous, and potassium at the two last growth stages is at least half of the total demand over the whole plant life, fertilization should be fractioned to ensure nutrient necessities at the end of the plant cycle. One of the possible causes of low yield of Venezuelan sesame could be low offer of nitrogen, phosphorous, and potassium at the last growth stages, because of fertilization in Venezuela for sesame is done in only one portion at the beginning of the crop cycle.

\section{CONCLUSIONS}

For both sesame cultivars evaluated, the order of macronutrients extraction was the same: nitrogen higher than potassium, potassium higher than calcium, calcium higher than phosphorous, phosphorous higher than magnesium, and magnesium higher than sodium. The order of micronutrients extraction was also the same: iron higher than zinc, zinc higher than cupper, and cupper higher than manganese. What was different for both cultivar were the rates of nutrient accumulation in the commercial product of sesame (seed): more than $30 \%$ of the nutrient extraction accumulated in seed was identified for nitrogen, phosphorous, copper, zinc, and manganese in UCLA-90; and for nitrogen, phosphorus, magnesium, and zinc in Fonucla. Results suggest calcium remobilization for both cultivar, and only for UCLA-90 of nitrogen, phosphorous, and magnesium.

\section{ACKNOWLEDGEMENT}

To the Consejo de Desarrollo Científico, Humanístico y Tecnológico (CDCHT) of Universidad Centroccidental Lisandro Alvarado for financial support of the project 042-AG2009, Calibración de Nutrientes requeridos por el Ajonjolí (Sesamum indicum L.), from which this paper was derived.

\section{Disclaimer}

Both authors made significant contribution to the document. Both agree to publish it, and declare there is no interest conflict in this study. 


\section{REFERENCES}

Arriel, N., Firmino, P., Beltrao, N., Soares, J., Araujo, A., Silva, G., and Ferreira, A. (2007). A cultura do gergelim. Informação Tecnológica-Coleção Plantar. Empresa Brasileira de Pesquisa Agropecuaria (EMBRAPA), Brasilia, Brasil. 98pp.

Badshan, S., Khalil, S., Jalal, F., Baseer, A., Suleman, M., Khan, H., and Zaheer, S. (2017).Influence of nitrogen and row spacing on sesame (Sesamum indicum L.) growth and yield attributes. Pure and Applied Biology.6(1):116-124. DOI: https://doi.org/10.19045/bspab.2017.60004

Baskar, M., Solaimalai, A., Kumar, A.,andPalanisamy, A.(2017). Residual effect of fly ash, farmy yard manure and fertilizers applied to groundnut on growth parameters, nutrient uptake, yield of sesame and post-harvest soil available fertility status in groundnut - sesame cropping system in northeastern zone of Tamil Nadu. International Journal of Current Microbiology and Applied Sciences.6(6):2917-2923.DOI: https://doi.org/10.20546/ijcmas.2017.606.3

Bender, R.,Haegele, J., and Below, F.(2015). Nutrient uptake, partitioning, and remobilization in modern soybean varieties. Agronomy Journal.107(2):563-573. DOI: doi:10.2134/ agronj14.0435

Bregliani, M., Temminghoff, E., van Riemskijk, W., and Haggi, E. (2006). Nitrogen fractions in arable soils in relation to nitrogen mineralization and plan uptake. Communications in Soil Science and Plant Analysis.37(11-12):1571-1586. DOI: https://doi.org/10.1080/00103620600710124

Couch, A., Jani, A., Mulvaney, M., Hochmuth, G., Bennett, J., Gloagen, R., Langham, R.,andRowland, D.(2017). Nitrogen accumulation, partitioning, and remobilization by diverse sesame cultivars in the humid southeastern USA. Field Crops Research.203(2017):55-64. DOI: https://doi.org/10.1016/j.fcr.2016.12.012

Dos Santos, M., Ribeiro, M., De Albuquerque, J., Lins, H., Barros, A., Bezerra, F., Da Silveira, L., Soares, E., andDe Souza, A.(2018). Production performance of sesame cultivars under different nitrogen rates in two crops in the Brazilian semi-arid region. IndustrialCrops and Products.124(1):1-8.DOI: https://doi.org/10.1016/j.indcrop.2018.07.015

Food and Agriculture Organization of the United Nations. (2019).FAOSTAT. Available at: <http:// faostat.fao. org >. Accessed on: 27 April 2019

Fukuda, Y., Nagata, M., Osawa, T., and Namiki, M. (1986). Contribution of lignan analogues to antioxidative activity of refined unroasted sesame seed oil. Journal of the American Oil Chemist's Society.63(8):1027-1031. DOI: doi:10.1007/BF02673792

Gaspar, A., Laboski, C., Naeve, S., and Conley, S.(2017). Phosphorus and potassium uptake, partitioning, and removal across a wide range of soybean seed yield levels. Crop Science.57(4):2193-2204.

Havlin, J.L., Beaton, J.D., Tisdale, S.L., and Nelson, W.L.(1999).Soil fertility and fertilizers; an introduction to nutrient management. $6^{\text {th }}$. Edition. Upper Saddle River, Prentice Hall. 499pp.

Jat, L., Yadav, S., Dhayal, B., Yadav, G., Choudary, K., and Bera, M.(2017). Effect of sulphur fertilization and varieties on sulphur use efficiency, yield attributes and yield of sesame. Journal of Pharmacognosy and Phytochemistry. 6(4):717-720.

Kronzucker, H.J., Coskun, D., Shulze, L.M., Wong, J.R., andBritto, D.T.(2013). Sodium as nutrient and toxicant. Plant and Soil.369(1-2):1-23.DOI: https://doi.org/10.1007/s11104-013-1801-2 
Laurentin, H., Montilla, D.,andGarcia, V.(2004).Relación entre el rendimiento de ocho genótipos de ajonjolí (Sesamum indicum L.) y sus componentes. Comparación de metodologias. Bioagro. 16(3):153-162.

Montilla, D., andCedeño, T. (1991). Fonucla. Nueva variedad de ajonjolí. Bioagro.3(2):52-54.

Patel, H., and Raj, A.(2017). Nutrient content as well as uptake of summer sesame as affected by nitrogen, phosphorous and biofertilizer under South Gujarat condition. International Journal of Chemical Studies.5(6):1-4.

Ramakrishna, B., Manasa, V., and Chandranath, H.(2017). Effect of sources and levels of sulphur on uptake of major nutrients by sesame (Sesamum indicum L.) and post harvest nutrient status in soil. Bulletin of Environment, Pharmacology and Life Sciences.6(10):66-70.

Ribeiro, R., Tavares, J., Dos Santos, M., Barros, A., Costa, L., and Silveira, L.(2018). Growth dynamics of sesame cultivars. Revista Caatinga.31(4):1062-1068.DOI: https://doi. org/10.1590/1983-21252018v31n430rc

Rodríguez, Z.F., Mármol, L.E., Martínez, J., and Montiel, M. (2009). Acumulación total y por órganos de macronutrientes en plantas de yuca (Manihot esculenta Crantz) cv. Tempranita en la altiplanicie de Maracaibo. Revista de la Facultad de Agronomía.26(4):470-489.

Sadeghian-Khalajabadi, S., Mejía-Muñoz, B., \& Arcila-Pulgarin, J.(2006). Composición elemental de frutos de café y extracción de nutrientes por la cosecha en la zona cafetera de Colombia. Cenicafe.57(4):251-261.

Sanchez-Reinoso, A., Nieto, M., Dossmann, J., Camacho-Tamayo, J., andRestrepo-Diaz, H.(2019). Nutrient uptake, partitioning, and removal in two modern high-yielding Colombian rice genotypes. Journal of Plant Nutrition.42(18):2373-2387. DOI: https://doi.org/10.1080/019 04167.2019.1659334

Shehu, H.(2014). Uptake and agronomic efficiencies of nitrogen, phosphorous and potassium in sesame (Sesamum indicum L.). American Journal of Plant Nutrition and Fertilization Technology. 4(2):41-56.DOI: doi:10.3923/ajpnft.2014.41.56

Tamagno, S., Balboa, G., Assefa, Y., Kovacs, P., Casteel, S., Salvagiotti, F., García, F., Stewart, W., andCiampitti, I.(2017). Nutrient partitioning and stoichiometry in soybean: a synthesisanalysis. Field Crop Research.200:18-27.DOI:https://doi.org/10.1016/j.fcr.2016.09.019

Yuhui, G., Guojun, C., Lichun, W., and Shuhua, W.(2019). Potassium accumulation, partitioning, and remobilization in high-yield spring maize in Northeast China. Journal of Plant Nutrition.42(11-12):1366-1377. DOI: doi:10.1080/01904167.2019.1609501

Zhou, B., Serret, M., Pie, J., Shah, S., ans Zhijian, L. (2018). Relative contribution of nitrogen absorption, remobilization, and partitioning to the ear during grain filling in Chinese winter wheat. Frontiers in Plant Sciences 9:1351.DOI: https://doi.org/10.3389/fpls.2018.01351 